\title{
Lexis
}

Journal in English Lexicology

$5 \mid 2010$

Lexicology \& Stylistics

\section{John McGahern's stylistic and narratological art}

Beatrix Busse, Dan Mclntyre, Nina Nørgaard and Michael Toolan

\section{(2) OpenEdition}

\section{Journals}

Electronic version

URL: http://journals.openedition.org/lexis/530

DOI: $10.4000 /$ lexis.530

ISSN: 1951-6215

\section{Publisher}

Université Jean Moulin - Lyon 3

\section{Electronic reference}

Beatrix Busse, Dan McIntyre, Nina Nørgaard and Michael Toolan, « John McGahern's stylistic and narratological art », Lexis [Online], 5 | 2010, Online since 15 October 2010, connection on 01 May 2019. URL : http://journals.openedition.org/lexis/530 ; DOI : 10.4000/lexis.530

\section{(9) $(\mathcal{\Theta \Theta}$}

Lexis is licensed under a Creative Commons Attribution-NonCommercial-NoDerivatives 4.0

International License. 


\title{
John McGahern's stylistic and narratological art
}

\author{
Beatrix Busse ${ }^{1}$ \\ Dan McIntyre ${ }^{2}$ \\ Nina Nørgaard ${ }^{3}$ \\ Michael Toolan ${ }^{4}$
}

\begin{abstract}
The Irish writer John McGahern is acknowledged as a master stylist in both his novels and his short stories. In this article we discuss the stylistic and narratological factors that contribute to the artistry in McGahern's short story writing. We analyse three stories: "A Slip-up", "All Sorts of Impossible Things", and "Creatures of the Earth", using a combination of qualitative and quantitative methodologies. The stylistic devices that we concentrate on are speech and thought presentation, negative polarity, lexico-semantic foregrounding, prospection and projection, collocation and semantic prosody, and keyness. We argue that by analysing these devices it is possible to gain an insight into the way in which McGahern draws the reader into his stories and generates empathetic responses to his characters. Consequently, these stylistic techniques may be seen as integral to McGahern's style as a writer.
\end{abstract}

Keywords: style - McGahern - keyness - negation - speech and thought presentation empathy

$* * *$

\section{Résumé}

John McGahern, écrivain irlandais, est reconnu comme étant un styliste d'exception, que ce soit dans ses romans ou dans ses nouvelles. Dans cet article, nous analysons quelques-uns des traits stylistiques et narratologiques qui contribuent à faire de John McGahern un maître de la nouvelle. Nous proposons une étude qualitative et quantitative de trois nouvelles, «A SlipUp », "All sorts of Impossible Things » et "Creatures of the Earth», fondée sur la présentation des paroles et des pensées, la polarité négative, le foregrounding lexicosémantique, l'anticipation et la projection, la collocation et la prosodie sémantique ainsi que la fréquence d'utilisation de mots-clés. La thèse défendue ici est que l'étude de ces éléments permet de comprendre comment McGahern parvient à impliquer le lecteur dans ses récits et à générer de l'empathie pour ses personnages. En conséquence, ces traits stylistiques peuvent être perçus comme faisant partie intégrante de l'art narratif de McGahern.

Mots-clés : style - McGahern - fréquence d'utilisation de mots-clés - négation - présentation des paroles et des pensées - empathie

\footnotetext{
${ }^{1}$ University of Bern, Switzerland: beatrix.busse@ens.unibe.ch

${ }^{2}$ University of Huddersfield, England: D.McIntyre@hud.ac.uk

${ }^{3}$ University of Southern Denmark, Denmark: noergaard@language.sdu.dk

${ }^{4}$ University of Birmingham, England: M.Toolan@bham.ac.uk
} 


\section{Introduction}

At a recent international short story conference held in Cork, an opening session invited four of Ireland's leading contemporary writers of short stories (Mary Morrissey, William Wall, Claire Keegan, and Colm Toibin) to talk about the literary influences on their work. Each in turn singled out John McGahern as a particularly inspiring precursor, describing his short fiction as especially fresh and liberating to them when they began writing. We concur with this recognition of his influence, and would echo others (see, for example, the recent special issue on him of the Journal of the Short Story in English: Maisonnat [2009] in regarding him as the leading Irish writer of fiction in the latter part of the twentieth century (he died in 2006). The writer Joseph O'Connor cites one of the "short, plain sentences" in the story "Sierra Leone": Her hair shone dark blue in the light, and remarks: "It is a sentence that could be written by almost anyone, but few writers are as aware as McGahern was of that strange ache in the heart caused by ordinary precise words, placed carefully, in order, quietly" [O'Connor 2008: 17]. McGahern is one of those authors often called "a writer's writer", which we interpret as alluding to something exceptional, distinctive, and powerful in his style and technique. What then is the nature of McGahern's unique style? In this article, based on our several presentations to the Cork conference, we offer a synthesis of our stylistic analyses of key features of his short story style. Our commentary is remote from anything like a definitive characterization; to begin with, it considers the linguistic detail in just a few of his stories only, and is entirely silent about his novels. Rather it is offered as notes towards the full account of McGahern's style that his narrative art deserves.

The essay that follows is organized into eight sections, each devoted to a significant aspect of McGahern's narrative style in the three stories we have analysed in detail ("A Slipup", "All Sorts of Impossible Things", and "Creatures of the Earth"; hereafter these titles will sometimes be abbreviated as "Slip-up", "Impossible Things" and "Creatures", respectively). These eight aspects of McGahern's narrative style, we suggest, form an interrelated set, capturing some of the characteristics which make his writing so distinctive. Superficially our topics may seem disparate - negation, speech and thought presentation, lexico-semantic foregrounding, strategies for embedding discourse and creating 'islands' of direct speech, narrative reticence and retroversion rather than dynamism - but taken together they powerfully contribute to the articulation of a situation, and often at the story's close a key poignant moment in that situation, which we take to be a hallmark of McGahern's writing. These stylistics resources are thus, we propose, crucial means by which McGahern draws the reader into a story, causing them to engage with one or more of its characters, and to empathize with them. Without that particular and careful deployment of each of these resources, the reader's involvement and empathy, their palpable experiencing of the articulated situation, would be greatly reduced.

\footnotetext{
${ }^{5}$ Opening words of a one-page draft commentary by McGahern on Listowel co. Kerry, catalogued as non-fiction item P71/1377 in the National University of Ireland, Galway archive of his work. http://archives.library.nuigalway.ie/cgi-bin/FramedList.cgi?P71

All page references to stories by McGahern are to Creatures of the Earth: New and Selected Stories (London: Faber, 2006).
} 


\section{Negative polarity in narrative discourse. Indicative case: "A Slip-up"}

As argued elsewhere [Nørgaard 2007], negative polarity is a significant meaning-making resource worth considering in the analysis of literary texts. In the following, we examine the use of negative polarity in "A Slip-up", in order to demonstrate how McGahern employs this particular linguistic device as a fairly subtle means of meaning construction.

"A Slip-up" is a story about an elderly couple, Agnes and Michael, who have sold their farm and retired to London. As a fixed routine they go to Tesco's every morning, where Agnes does the shopping while Michael is waiting outside, daydreaming about the farm. Having done their shopping, Michael has a beer at the pub, while Agnes prepares lunch at home. However, on this particular day Michael does not return for lunch. Agnes gets worried, a search is launched, and Michael is finally found outside Tesco's where he is still waiting for Agnes who has forgotten to collect him. The story ends at the pub where Michael feels very uncomfortable about this little - but for him major - slip-up.

In terms of their linguistic form, negatives are marked constructions since, typically, they are formed by adding extra (negative) linguistic material to their positive counterpart (friendly vs. unfriendly and not friendly). Negatives may be divided into three general categories, morphological negation (unfriendly), syntactic negation (not friendly) and inherent negation (hostile) (cf. Givon [1993: 202]), of which morphological and syntactic negation are formal categories while inherent negation is a semantic (and thereby less sharply delimited category of words which are positive in form but arguably negative in meaning (cf. e.g. Jespersen 1917: 42). Of interest to literary critics, however, is not so much the formal markedness and different formal categories of negative polarity as the likewise marked pragmatic function of such constructions.

According to psycholinguistic research, negatives are more difficult - and take more time - to process than positive constructions, since the decoding of a negative construction cognitively involves the establishment of the positive counterpart of the construction as well as the cancellation of it (cf. e.g. Clark and Clark [1977]). Thus the decoding of e.g. "Peter is not a teacher" involves both the establishment of the proposition that "Peter is a teacher" and the cancellation of it. In some sense, negatives may furthermore be considered more oblique and obscure and thereby less informative than alternative positive constructions: Somebody may tell you that Peter is not a teacher, but what then is he? A mechanic? A nurse? A carpenter? All this has pragmatic repercussions if Grice's maxims of quantity and manner (i.e. the cooperative principles of making one's contribution to communication as informative as possible and of avoiding obscurity) are not to be flouted (cf. Grice [1975]. According to Leech, there must be a good reason to use a negative when a positive construction could have been employed instead: "A negative sentence will be avoided if a positive one can be used in its place. Moreover, [...] when negative sentences ARE used, it will be for a special purpose." [Leech 1983: 101].

But what are the implications of all this for the analysis of literature? If we take a look at the introductory paragraph of "A Slip-up", we see that the linguistic feature of negative polarity - more specifically syntactic negation - is here employed quite extensively by McGahern:

There was such a strain on the silence between them after he'd eaten that it had to be broken. "Maybe we should never have given up the farm and come here. Even though we had no one to pass it on to," Michael said, his head of coarse white hair leaning away from his wife as he spoke. What had happened today would never have happened if they'd stayed, he thought, and there'd be no shame; but he did not speak it. ("Slip-Up", p. 83, bold added) 
In the final clause of this passage, an account of Michael's thoughts is concluded by the statement that "he did not speak it". Since the construction tells us what Michael does not do but not what he does do, the negative is arguably less informative than a potential positive alternative. Interestingly, leaving out the construction would express more or less the same experiential meaning, but because of McGahern's use of the negative construction, the positive counterpart, "speaking it" (i.e. telling his wife what he is thinking), is established and negated by the chosen wording. Thereby, the statement that Michael "did not speak it" tends to make us aware that he could have done so and makes us consider the significance of his silence, i.e. the basic tension and lack of communication between husband and wife and the importance of the slip-up to Michael.

Similarly, in the treatment of negative polarity by cognitive linguistics, emphasis is given to the fact that "negating the frame evokes the frame" [Lakoff 2004]. This is demonstrated neatly by Lakoff's famous example of the proposition "Don't think of a pink elephant" which, he suggests, immediately establishes an image of a pink elephant in the mind of the addressee. This approach is developed further by Paul Werth's text world theory [1999], which is concerned with the ability of discourse to construct mental images - which Werth calls text worlds - in our minds. In Werth's view [1999: 253-254], "there are forms of negation [...] which not only delete an entity, but also introduce it at the same time", thereby creating a textual sub-world within a given text world. These cognitive linguistic insights seem useful for describing and understanding how meaning is created linguistically by the remaining negatives in McGahern's introductory passage.

If we look at the two other examples of syntactic negation in the final sentence, never happened and no shame, it is quite obvious that these negative constructions hold text-worldbuilding properties in Werth's terms. In combination with the conditional if-construction, never happened and no shame thus construct a world where something did happen and a feeling of shame does exist, thus foreshadowing the narrative to follow, creating suspense and expectations for the revelation of something (rather) shameful.

The last negatives in this extract appear to have similar text-world-building properties. The hypothetic "maybe we should never have given up the farm", constructs the world of having given up the farm in the sense that the negative text-world is a hypothetic - and for Michael ideal - world which clashes with the text-world of its positive counterpart invoked by the negative construction, i.e. the reality of the retired couple's present life. With no one it is the other way around. Here the negative text-world is reality which, through its negative form, invokes its positive counterpart where the couple would have had someone (e.g. children) to pass the farm on to. Altogether, quite a lot of meaning is compressed into these lines, largely because of the use of negative constructions which appear to be more - rather than less informative than possible positive alternative constructions.

Later in the story, negative polarity occurs in the description of Agnes and Michael's daily visit to Tesco's:

When they reached Tesco's he did not go in. The brands and bright lights troubled him, and as she made all the purchases he had no function within anyhow. So on dry days he stayed outside with the empty shopping bag ("SlipUp", p. 85, bold added)

According to Israel [2004: 708], "negation appears specially suited to mark the exception to a salient pattern." This observation is well in line with Werth's text world theory, according to which the negative may here be seen as "an instruction to modify the world-building parameters which have already been set up" and as "a redefinition of the text-world" [Werth 
1999: 252]. While going to Tesco's sets up expectations that one will enter the building and do some shopping, this common pattern of action is here negated, and the negation arguably makes us more acutely aware of the significance of Michael's staying outside than would a positive construction such as "he waited outside". In contrast to the world of Michael's daydreaming where he does different jobs, fixing things back at the farm, these lines capture his present life where his only job is to accompany his wife to Tesco's every day - but even here he has no function but to stand outside with an empty shopping bag.

With empty we have an example of inherent negation, i.e. a word that does not have a negative form (is not marked as negative) but whose meaning is clearly of a negative nature. In this sentence, empty could have been left out with little change of meaning, but by its presence, the negative polarity of the inherent negation appears to add to the image of impotence that is created by the negative constructions preceding it as well as by the explicit mentioning of Michael's impotent rage ("Slip-Up", p. 87) a little later in the narrative.

When accounting for the meaning created by the negative polarity highlighted in the following extract, the linguistic polyphony involved seems worth considering.

When he first began to come with her [to Tesco's] after retiring, the off-licence assistants used to bother him by asking if they could help. As he said "No thanks," he wanted to tell them that he never drank in the house. ("Slip-up", 85, bold added)

Proponents of the linguistic theory of polyphony known as ScaPoLine (cf. Nølke [2006] focus on the ability of negatives (as well as other linguistic constructions) to encode different voices, or viewpoints, in texts. The different viewpoints may belong to different characters, the narrator, public opinion, an earlier "version" of the current speaker, etc. and may be realised linguistically at sentence level or even by a single word. If, for instance, somebody tells his neighbour that "my wife is not pregnant", the negation carries instructions that the sentence holds more viewpoints, or voices, than one. Viewpoint 2, "my wife is not pregnant" negates, and thereby entails, another viewpoint, Viewpoint 1, i.e. "my wife is pregnant." The choice of the negative construction is not a random choice out of the blue, but a linguistic way of coding the implicit or explicit view that somebody believes/expects/hopes/etc. that the woman in question is pregnant. The responsibility for the positive viewpoint is usually established by the context of the sentence. In the present case, the context might reveal that the addressee explicitly or implicitly believes that the woman is (or may be) pregnant, but Viewpoint 1 could likewise belong to an earlier "version" of the speaker who might have thought or hoped that his wife was pregnant.

In the extract quoted above, Viewpoint 2, he never drank in the house entails Viewpoint 1, he drank in the house. In this example, the immediate context of the negative clause enables us to establish who is responsible for Viewpoint 1. Since the off-license assistants offer Michael their services, he believes that they believe he drinks at home. So while Michael is responsible for Viewpoint 2, Viewpoint 1 must be ascribed to the off-licence assistants. Even if they never actually voiced the claim that Michael is drinking at home, it still seems that what is encoded by the negative construction here is 'their words (as Michael imagines them) in his words' (cf. Bakhtin's concepts of 'the dialogic word' and 'your word in my word').

Another example of polyphony occurs towards the end of the story when Michael and Agnes enter the pub in the evening:

All the saloon regulars looked unusually happy and bright as they greeted the old couple in the Royal, and when Michael proffered the coins for the Guinness and 
pint of Bass, Dennis pushed them away. "They're on the house tonight, Michael. You have to make up for that missed bottle of Bass tonight." ("Slip-Up", p. 88, bold added)

Here, the morphological negation of unusually happy (Viewpoint 2) entails the meaning of 'usually happy', i.e. as happy as usual, (Viewpoint 1), but unlike the previous example, it is slightly more difficult to determine unambiguously who is responsible for the two viewpoints in this example. In the immediate co-text preceding the passage quoted above we have been told that, after his slip-up, Michael does not feel like going to the pub, as they normally do; and in the lines following the passage, we are told that "blindly he carried the drinks towards Agnes at the table" - both indicating that the negative construction may be seen as a subtle instance of focalisation. That Michael in embarrassment over his little mishap is actually the one who believes that everybody is unusually happy (at his expense) is supported later by Agnes' comment that "You see it was all in your mind, Michael. Everybody is the same as usual"; but then what she adds as an afterthought, "Even happier", creates an interesting cotextual dissonance and viewpoint shift. At this point, it is no longer possible to determine whether the alleged unusual happiness of the pub regulars, expressed by the negative construction unusually happy, reflects the situation seen from Michael's perspective, from the collective perspective of the old couple, or whether the other people in the pub, in fact, are happier than usual. As a matter of fact, we would claim that some of the power of the passage resides in this indeterminacy.

While our observations made about McGahern's use of negative polarity focus on the occurrence of negatives at the lexico-grammatical level of the text, negative polarity may also be seen as a narrative strategy at a more general level of the text. As a rule, narratives must have, built into their onset, a lack or problem or difficulty; thereafter the sequence of narrated events can be interpreted as reporting an attempt to fill, solve, or resolve the lack or difficulty. So at the narrative level of the story, a general kind of inherent negation can be expected somewhere in the opening situation of the story/fabula (it may not get told first, in the narrative discourse, although it often is). Arguably there is a doubled lack in the opening situation of the core story of "A Slip-up": while Michael waits outside Tesco's, there is no Agnes to collect him; when Agnes has Michael's lunch prepared, there is no Michael arrived home to eat it. ${ }^{6}$

\section{Speech and thought presentation. Indicative cases: "A Slip-up" and "Creatures of the Earth"}

The sophistication and subtlety of the embedding of characters' speech and thought in the ongoing narrative is also distinctive in McGahern's short story style. Relatedly, analysing speech and thought presentation in stories such as "Creatures of the Earth" and "A Slip-up" is not a straightforward task. "Creatures of the Earth," for example, is rich in the presentation of various forms of characters' thoughts, which are generally more difficult to identify in narratives than forms of speech presentation. "A Slip-up," by contrast, abounds in embedded speech presentation, and large sections of the story describe Michael working on the farm he has in fact given up. But it is only in context that we realize that Michael is only imagining working the farm: the style of narration makes the farm-work seem quite real (just as real as the trip to Tesco's) rather than imagined. This feature of the story poses the question of how

\footnotetext{
${ }^{6}$ A more extensive account of the form and functions of negative polarity and of the various linguistic approaches to the phenomenon can be found in Nørgaard [2007] on which the brief review here is based.
} 
to evaluate the relation between reports of his imagination and narration of actual events, and how to annotate these sequences.

This year he must move the pit to higher ground. Last winter the rats had come up from the lake - but why had she not called him? Had she no care? Was she so utterly selfish? [McGahern 1992: 87]

We would point particularly to such moments as these, as powerful in their requiring of reader-engagement, rather in the high modernist style of Virginia Woolf's novels, but here in the much more compressed setting of the short story. While everything here is Michael's Free Indirect Thought, the reader must understand that the first half comes from the imagined world which Michael enters during his Tesco vigils (and perhaps only then), while the dash in the second sentence marks a deictic shift, back to the immediate story world in which Michael's thoughts about his present time situation, seemingly abandoned by Agnes, are conveyed. Combining FIT with deictic shift between distinct story worlds, this creates a powerful sense of immersion within Michael's consciousness.

This section draws on corpus-stylistic methods to investigate discourse presentation in the two McGahern short stories. We aim to show how the forms of discourse presentation (speech or thought; direct, indirect or free indirect, embedded) relate to one another; to suggest what the effects of these interrelationships are on the reader; and to say what is distinctive about McGahern's way of rendering character's speech and thought. Both stories were analysed and marked up electronically, applying the categories and model set out in Semino and Short [2004], outlined briefly below; this enabled us to see whether McGahern's discourse presentation tendencies match or depart from the general norms for $20^{\text {th }}$-century narrative fiction identified in the Semino and Short study. We link our quantitative profiling to qualitative assessments of the stories' discourse presentation, to show how that discourse presentation shapes our perceptions of characters and their inner worlds as well as what literary critics have called the inward looking perspective in McGahern's fiction. In this respect, one particular emphasis will be on embedded discourse presentation.

\subsection{The Semino and Short model, briefly described}

Semino and Short [2004] extend the model of discourse presentation as presented in Leech and Short [(1981) 2007] by not only making a distinction between speech, thought and writing presentation, but also by introducing new parallel categories of each scale, such as a category for a minimal presentation of a character's speech - NV and a category in which a character's inner state of mind is reported - NI. The different modes on both the speech and thought presentation scale are illustrated in Tables $1 \mathrm{a}$ and $1 \mathrm{~b}$.

\begin{tabular}{|l|l|l|l|l|l|}
\hline NV & NRSA & IS & FIS & DS & FDS \\
\hline $\begin{array}{l}\text { narrator's } \\
\text { presentation } \\
\text { of voice }\end{array}$ & $\begin{array}{l}\text { narrator's presentation of } \\
\text { speech acts }\end{array}$ & $\begin{array}{l}\text { indirect } \\
\text { speech }\end{array}$ & $\begin{array}{l}\text { free indirect } \\
\text { speech }\end{array}$ & $\begin{array}{l}\text { direct } \\
\text { speech }\end{array}$ & $\begin{array}{l}\text { free direct } \\
\text { speech }\end{array}$ \\
\hline
\end{tabular}

Table 1a: Speech presentation categories (Leech and Short, 1981, 2007, and Semino and Short 2004) ${ }^{7}$

\footnotetext{
${ }^{7}$ The writing presentation scale is similar to the speech presentation scale in Semino and Short [2004], but will not be further elaborated on here because writing presentation does not occur in the two short stories under investigation.
} 


\begin{tabular}{|l|l|l|l|l|l|l|}
\hline NI & NT & NRTA & IT & FIT & DS & FDS \\
\hline $\begin{array}{l}\text { internal } \\
\text { narration }\end{array}$ & $\begin{array}{l}\text { narrator's presentation } \\
\text { of thought }\end{array}$ & $\begin{array}{l}\text { narrator's } \\
\text { presentation of } \\
\text { thought acts }\end{array}$ & $\begin{array}{l}\text { indirect } \\
\text { thought }\end{array}$ & $\begin{array}{l}\text { free } \\
\text { indirect } \\
\text { thought }\end{array}$ & $\begin{array}{l}\text { direct } \\
\text { thought }\end{array}$ & $\begin{array}{l}\text { free } \\
\text { direct } \\
\text { thought }\end{array}$ \\
\hline
\end{tabular}

Table 1b: Speech and Thought presentation categories (Leech and Short, 1981, 2007, and Semino and Short 2004)

\subsection{Discourse presentation in "A Slip-up" and "Creatures of the Earth" - quantitative results}

Table 2 shows the percentages of tags identified for speech and thought presentation. It also displays the results for ambiguous annotations of discourse presentation, which are summarized under the term "other." Here the term tag denotes not only a reporting clause, such as "he said," but also any wording that implies a communicative act. For example, in

"What time is it now?"

"Five after three, Michael.” Denis was smiling. (“Slip up”, p. 87)

"What time is it now?" is labeled as direct speech (DS), as is the stretch "Five after three, Michael," while "Denis was smiling" is labeled as narration (N). The percentages of tags attributed to the different stretches in the two short stories are given in relation to all the annotations made.

In terms of frequency, there are large imbalances between the two modes of presentation when the two short stories are compared, as Table 2 illustrates. Speech presentation is the more frequent mode of discourse presentation $(28.42 \%$ of the tags are speech presentation tags in "A Slip-up" and $30.42 \%$ of all the tags are speech presentation tags in "Creatures").

\begin{tabular}{|l|l|l|}
\hline \multirow{2}{*}{$\begin{array}{l}\text { discourse presentation mode and } \\
\text { narration }\end{array}$} & percentages \\
\cline { 2 - 3 } & "A Slip-up" & "Creatures" \\
\hline speech presentation & $28.42 \%$ & $30.42 \%$ \\
\hline thought presentation & $19.02 \%$ & $28.94 \%$ \\
\hline other & $14.15 \%$ & $5.43 \%$ \\
\hline
\end{tabular}

Table 2: Percentages of tags identified as discourse presentation in "A Slip-up" and "Creatures"

However, in "Slip-up" and "Creatures," narration is the mode with the highest frequency. The figures for thought presentation are different in the two short stories: in "A Slip-up," $19.02 \%$ of the tags are thought presentation and, in "Creatures," $28.94 \%$ of the tags are identified as thought presentation. While the percentage rates of tags for speech presentation remains constant in the two short stories, it seems to be the discourse presentation mode of thought presentation which is exploited by McGahern. In comparison with the Semino and Short [2004] results, stretches identified as narration, however, occur far more frequently in both McGahern short stories than in the Semino and Short [2004] corpus (see Table 3). This illustrates the strong narratological control needed in the two short stories.

\footnotetext{
${ }^{8}$ Throughout, the tables provide only the figures for clear categories of discourse presentation (and not those for ambiguous categories).
} 


\begin{tabular}{|l|l|l|l|}
\hline \multirow{2}{*}{$\begin{array}{l}\text { discourse presentation } \\
\text { mode and narration }\end{array}$} & \multicolumn{3}{l|}{ percentages of discourse presentation } \\
\cline { 2 - 4 } & "A Slip-up" & "Creatures" & $\begin{array}{l}20^{\text {th }} \text {-century narrative fiction } \\
\text { (Semino and Short 2004) }\end{array}$ \\
\hline speech presentation & $28.42 \%$ & $30.42 \%$ & $50.06 \%$ \\
\hline thought presentation & 19.02 & $28.94 \%$ & $24.04 \%$ \\
\hline writing presentation & $0 \%$ & $0 \%$ & $1.65 \%$ \\
\hline Narration & $36.59 \%$ & $37.21 \%$ & 20.99 \\
\hline Other & $14.15 \%$ & $5.43 \%$ & $2.9 \%$ \\
\hline
\end{tabular}

Table 3: Percentages of discourse presentation tags and narration presentation tags identified in "Slip-up" and "Creatures" and in the Semino and Short [2004) corpus of narrative fiction

It is more difficult to interpret the quantitative results for tags of thought presentation. "Slipup" shows parallel figures to those in Semino and Short [2004]. In "Creatures," thought presentation is comparatively more frequent than in the $20^{\text {th }}$-century corpus.

\subsection{Distributions of speech and thought presentation in "A Slip-up" and "Creatures of the Earth"}

It is striking in McGahern's style that where speech is presented, the most direct and most character-oriented modes of speech presentation, DS and FDS, dominate while other types of speech presentation are less frequent, as Table 4 illustrates.

\begin{tabular}{|l|l|l|l|l|l|l|}
\hline $\begin{array}{l}\text { speech presentation } \\
\text { mode }\end{array}$ & NV & NRSA & IS & FIS & DS & FDS \\
\hline percentages & $2.44 \%$ & $1.46 \%$ & $2.93 \%$ & $0 \%$ & $18.05 \%$ & $5.37 \%$ \\
\hline
\end{tabular}

Table 4: Percentages of tags of speech presentation in "Slip-up"

In "Creatures," also, the most direct versions occur most frequently, but this time the percentage of tags for FDS surpasses that for DS, as Table 5 illustrates.

\begin{tabular}{|l|l|l|l|l|l|l|}
\hline $\begin{array}{l}\text { speech presentation } \\
\text { mode }\end{array}$ & NV & NRSA & IS & FIS & DS & FDS \\
\hline percentages & 1.29 & 4.91 & 2.84 & 3.10 & 5.68 & 10.59 \\
\hline
\end{tabular}

Table 5: Percentages of tags of speech presentation in "Creatures of the Earth"

Despite these differences, the choice of the most character-oriented speech presentation modes in both short stories contributes to the effect of vividness and dramatization and reality. It should be noted, however, that in both "Slip-up" and "Creatures" a considerable number of these "direct" speech presentation instances are of embedded speech. Although the reader seems to be referred to events in the past through embedded speech, the fact that these references frequently are referred to by means of direct speech presentation makes these incidences more immediate rather than simply reported.

Within the discourse mode of thought presentation, the indirect thought presentation categories and Free Indirect Thought (FIT) occur more frequently, especially in "Creatures." In "Slip-up," IT and, especially, FIT are relatively prominent $5.37 \%$ IT and $4.88 \%$ FIT). As regards thought presentation in "Creatures", FIT is even more prominent: 39 instances, by comparison with 22 of IT, and 112 instances (all types) in total. 


\begin{tabular}{|l|l|l|l|l|l|l|l|}
\hline $\begin{array}{l}\text { thought presentation } \\
\text { mode }\end{array}$ & NI & NT & NRTA & IT & FIT & DT & FDT \\
\hline percentages & $3.90 \%$ & $1.95 \%$ & $1.46 \%$ & $5.37 \%$ & $4.88 \%$ & $1.46 \%$ & $0.00 \%$ \\
\hline
\end{tabular}

Table 6: Percentages of tags of thought presentation in "Slip-up"

\begin{tabular}{|l|l|l|l|l|l|l|l|}
\hline $\begin{array}{l}\text { Thought presentation } \\
\text { mode }\end{array}$ & NI & NT & NRTA & IT & FIT & DT & FDT \\
\hline percentages & $5.17 \%$ & $0.00 \%$ & $5.68 \%$ & $5.68 \%$ & $10.08 \%$ & $0.52 \%$ & $0.26 \%$ \\
\hline
\end{tabular}

Table 7: Percentages of tags of thought presentation in "Creatures of the Earth"

In "A Slip-up," the reader is confronted with Michael's imagination of working a farm and Michael switches between the present time and his imagination in the following stretch already quoted at the beginning of this section:

This year he must move the pit to higher ground. Last winter the rats had come up from the lake - but why had she not called him? Had she no care? Was she so utterly selfish? (p. 87)

In this example, the hyphen indicates the switch from his imagination working the farm to the thought presentation mode of FIT through which his anger at his wife for having forgotten him in front of Tesco's is expressed. Yet, these thoughts remain part of his mind and are never expressed openly to his wife.

In "Creatures," Mrs. Waldron's feelings of loss (her husband's death and the cat's disappearance) are expressed in FIT. In the following example, the FIT is characterized by a high proliferation of questions.

Her life with her father and mother had passed. Her life with her husband had now passed. Was her whole life, then, all nothing? Was it just what happened and the memory of those happening, like the old classmate she had once chanced upon in the ship's restaurant during a Holyhead-Dublin crossing? (p. 326)

The foregrounded status of thought presentation in "Slip-up" is further reinforced by the fact that the tags identified as FIT contain far more words, per tag, than the IT tags do (10 instances comprising 300 words). In contrast, IT is most frequently tagged, but these tags amount to a comparatively small proportion of the story's size in words (only $3.22 \%$; 11 instances totaling 105 words). A parallel pattern can be observed in "Creatures," where far more words ( $16 \%$ of the story total) occupy the category FIT than the IT one, although the latter is the second most frequent thought-presentation category.

\subsection{Direct Speech in McGahern's stories: the 'islanded' speech exchange}

Both DS and FDS show a character's words and bring with them a further faithfulness claim since they purport to be verbatim reports of the speech act value, the grammatical structure and the words of the utterance as well as its propositional content. Toolan has suggested [2001: 129] "the choice of direct speech reporting is also to accept a scenic slowing of pace, and enhanced focus on the specificity and detail of an interaction, and a greater pressure on the author to make such text redeemingly interesting." The latter factor may hold a clue to the function of forms of direct speech (free or framed) in McGahern's stories. As noted above, speech presentation is comparatively scarce in the stories (relative to Semino's and Short's norms). It may be that the scarcity in itself is a kind of foregounding. If 
McGahern deploys Direct Speech little more than half as much as other $20^{\text {th }}$ century fiction writers, might it be that the DS in his stories is particularly charged, or dramatically and interpersonally significant? In these respects, we tentatively propose, McGahern's use of DS may be distinct from the copious use of DS in typical $20^{\text {th }}$ century fiction to record routine or practical deliberation and relatively everyday forms of multi-party interaction and negotiation. How often, for example, are there in McGahern's stories "set piece" sequences of multiple turns of talk (in bar or restaurant, over dinner, in bed, or in a similar situation of potential extended exchange)? We suggest that these are strikingly rare, and that in his short story style it is the delimited and 'islanded' speech exchange, often comprising between two and four conversational contributions, that is the norm. Matching the reticent, inward-turned characters, speech is spare but carefully considered, intended to leave a mark (on the interlocutor and on the reader).

In "Slip-up," for example, the exchange between Michael and his wife after Michael is found is portrayed in DS and conveys Michael's anger not only at being "disturbed in his imagination working the farm," but also at his wife:

"Why did you leave me?" he asked angrily.

"Oh don't be mad at me, Michael. I must have forgot when I came out."

"What time is it now?"

"Five after three, Michael." Denis was smiling. "You've missed your bottle of

Bass, but hop in and I'll run you home." (p. 87)

This is the entirety of an 'island' of Direct Speech, preceded by two-and-a-half pages of narrative and followed by several lines of narrative and an (un-narrated) shift of setting (from the supermarket to their home) before the next two-turn conversational exchange.

In "Creatures", through stretches of embedded FDS the process of ageing and Mr. Waldron's dispassionate attitude to it is contrasted with that of his wife, who feels like a "relic" after her husband's death. Here is the entirety of one of these (few) islanded exchanges:

"We are no longer useful. It is as simple as that."

"It can't be that simple."

"Not complicated, then, either. They work with sick people but they are not ill.

They are outside and above all that. They have to be. They loom like gods in the eyes of most of these poor creatures. Now that I am sick I simply am no longer part of the necessary lie that works. I have to be shut out. Gods can never appear ill or wounded."

"You never behaved that way."

"I like to think I was a little different, but maybe not all that different either. Anyhow..." (p. 321)

We suggest that Direct Speech and Free Indirect Thought, although comparatively infrequent in the stories, have a central role in McGahern's narrative style. Direct speech and Free Direct Speech are two means of presenting to the reader (what purport to be) the characters' real words and emotions; and while FIT is a mixed form, in which the narratorial frame remains in place, it is sometimes yet more able to reveal - in a restrained way - the inner life of the character. This strategy of foregrounding the identified aspects of discourse presentation may lead to the question whether the stories' chiefly exploiting these kinds of discourse presentation reflect what Harmon [1976] has described as a more general preoccupation in Irish fiction with the private and the personal. 


\section{Embedded narration and embedded discourse presentation}

Instances of speech and thought presentation may involve the reporting of further speech or thought embedded within them (and this embedding can in theory recur many times). One character can be reported recalling their own or another's words or thoughts. An example from "Creatures" can serve: here, a stretch of NT (narratorial presentation of thought) is used to introduce an embedded segment of discourse presentation which the reader interprets as Mrs. Waldron's vivid memory:

She [Mrs. Waldron] found herself repeating the sentence long after she had closed the book, seeing elements of her own life and people she knew reflected in it, elements of that life seen and given a moral sweetness that was close to smiling. "Smith told me he's given up reading!" her husband informed her boisterously one evening years ago after he came home from the hospital.

"What's so funny about that?" (p. 322)

Here, the narration (again, exploiting a deictic shift) projects the reader back to an indefinite time "years ago." The subsequent direct speech question, without a supporting verb of communication, we infer to be Mrs. Waldron's response to her husband. But the latter half of this extract (along with the few lines of dialogue that follow it) we also understand is a Free Indirect Thought recalling by Mrs. Waldron in the story present, years later and after her husband's death. The embedded segment we know is over when the present-time narration resumes as follows (bold added): "Without reading, she would feel her whole life now to be spiritually idle." Mrs. Waldron's withdrawal to this and similar cherished memories seems to make the present more bearable to her. In memory, at least, she revives things she did with her husband long ago; and at the same time through this embedded direct mode of discourse presentation their relationship is vividly characterized for the reader.

Embedded discourse presentation is very prominent in "A Slip-Up" too $(16.4 \%$ as opposed to $12 \%$ in the Semino and Short corpus). There it projects the reader between the text worlds presented: the characters' mental worlds, their memories and the narrated present. In embedded speech presentation, direct discourse presentation categories are the most frequent hosts, but the categories of embedded speech presentation are often those that are at the most indirect end of the scale (such as eNRSA, eIS, and eNV), because they are easier to report than direct categories of the respective scales. In "Slip-up," this distribution is different because most of the embedded tags are direct forms. The effect of such embedding can be further illustrated by this example, in which Agnes recalls her conversation with Denis about Michael when the latter was lost, and then reports that conversation to Michael himself:

"What is it, Agnes?" Denis said. "Have you seen Michael?" I asked. "No." Denis shook his head. "He hasn't been in at all today. We were wondering if he was all right. It's the first time he's not showed up for his bottle of Bass since he had that flu last winter." "He's not showed up for his lunch either and he's always on the dot. What can have happened to him?" I started to cry. (p. 84)

This passage reports Agnes's fully-recalled words with Denis and seems intended also to convey to Michael the sincerity of her concern for him. Thus in the course of Agnes's pasttense telling to Michael of what she did - giving "an account of her conduct" - she embeds a seemingly verbatim present-tense-record of her earlier conversation with Denis. The deictic 
shift between the two textual worlds and the excessively detailed reporting (consider, for example, the repeated adverbial then and the insertion of inquit clauses such as Denis said and I asked) seem intended to justify her behavior and deflect Michael's complaint (childish, of course) that she had neglected him.

Through the embedding of stretches of discourse presentation the characters' mental words and their attempts to cope with their respective situations of exile, loss and separation, are created. The integration of the past and the imagination is shown in the present. The presentation of embedded stretches as DS in a sense asserts that these are not "just memories". Things past are important to and blended in the narrative present, a present in which the reader also is implicitly invited to participate.

\section{The language of humiliation}

\subsection{The phrase that rankles}

Over and over again, McGahern's reporting of direct speech, and characters' recall of that speech thereafter, show his brilliant sensitivity to face, identity, and sense of self-worth, which often has a gendered and sexual dimension. Often it is apparent that his main characters - his male characters at least - are rooted (or imprisoned) in a social world which, rightly or wrongly, they assume to be immensely judgemental. That world is quick to mock and belittle, slow or simply unable to love. We know from his Memoir that this was very much the world McGahern's father occupied and projected, but ultimately failed to impose on his son. Nothing is so leadenly expressed of course, or spelt out in these naked terms, in the stories: that is why McGahern's style is an art. Instead what we get in the stories are moments such as this, in "A Slip-up", when it is the pub landlord, Denis, who has driven around the local streets and found old Michael standing outside Tesco's, still waiting to be collected by Agnes:

"What time is it now?"

"Five after three, Michael." Denis was smiling. "You've missed your bottle of Bass, but hop in and I'll run you home." (p. 87)

It wouldn't have happened if we'd kept the farm. At least on the farm we'd be away from people, he thought obstinately as he put the food aside that he should have eaten hours before. He flushed like a child with shame as he heard again, "Five after three, Michael. You've missed your bottle of Bass, but hop in and I'll run you home," and thought that's how it goes, you go on as usual every day, and then something happens, and you make a mistake, and you're caught. It was Agnes who at last broke this impossible silence. (p. 87-88, bold added)

What is striking about the material here in bold is that it shows us Michael recalling Denis's words (in fact, hearing it again) immediately after the episode has been narrated - in the first three lines of the quoted extract - in the story discourse. Michael recalls the precise words, and then, in indirect thought, reflects on what he sees as their import: that they are public confirmation that he has 'fallen' from the usual standards of normality and respectability. Michael thinks in the same phrase, "as usual", that we noted in our Negation section was used by Agnes at first reassuringly and then with probably innocent but undercutting effect near the close of the story (the same as usual. Even happier...). But if you fail to maintain the usual, Michael thinks, "you're caught". Not just 'caught out', but caught, punished, beaten down, as, for example, Sharkey and Lennon would wish Coolcarra Queen had caught the hare (in 
"Impossible Things"), or Tommy McHugh suspects Mrs Waldron of trying to catch him (in "Creatures"). These characters' world is one where discipline and punishment are only just below the surface of ordinary conversation, whether it is about hopping in a car to be run home, or using binoculars to watch sheep or the sea.

Michael recalls Denis's words verbatim; but the most humiliating and infantilizing of them - unmanning, even - are Denis's invitation to Michael to hop in. Hopping in is semantically associated with casual informality, as of a movement involving minimal effort or burden, the slightest imposition or consequence. But that is not how Michael sees things; he cannot not 'hop in', but in hopping in he feels he has conceded that he is a dependent, in need of being 'rescued'. Denis has used the language of carers, and Michael (so recently, in his inner world, the vigorous capable farmer) feels himself submitting to being his elderly patient.

There is often in McGahern this focus on a particular locution, and perhaps a particular word within a brief locution, as the nucleus of some shaming or emasculating moment - quite possibly intended as a moment of informality or banter on the part of the interlocutor. That, at least, is one way of looking at a similar moment in "Impossible Things", which is similarly repeated in character-recollection within the story text. It comes when Tom Lennon declines James Sharkey's invitation, after they have been racing the hounds, to have a drink before heading home. Of his wife Tom says:

"I told her I'd be back for the dinner. If I'm in time for the dinner she might have something even better for me afterwards," Tom Lennon joked defensively. (p. 93)

The text is reasonably explicit that Lennon's defensiveness is to do with his poor health, in particular his deteriorating heart condition; it is equally clear that he is no longer capable of enjoying "something even better" after dinner. He is clearly as powerless as Michael in "A Slip-up". Nevertheless, it is Sharkey who, a short time later when drinking whiskey in Charlie's bar, resentfully recalls Tom's words. His recall of them is subtly triggered by his observing of the barman surreptitiously taking a drink, and doing so so swiftly and furtively that his disapproving wife will not see: Charlie's actions, so familiar to Sharkey, are presented as a kind of quick and unsatisfactory marital infidelity. And this, too, foregrounds the theme of sexual intimacy, not least to Sharkey, sensitive about his own lack of sexual partner:

While he [Charlie] waited for the coughing to die, he rearranged bottles on the shelves. The teacher [Sharkey] was so intimate with the subterfuge that he might as well have taken part in the act of love. "If I'm home in time for the dinner she might have something even better for me afterwards," he remembered with resentment. (p. 94)

\subsection{Vraisemblable textual detail and psychosexual significance: the case of the empty shopping bag}

In "A Slip-up", why does Michael carry an empty shopping bag, and why is it repeatedly mentioned in the narration? We suggest that answers to these questions point to another respect in which McGahern is a master storyteller: he is able to combine the said and the implied, the 'seemingly inconsequential' narrative detail with deep implications about characters' assumptions as to 'how to live as usual, so as not to be caught', in subtle ways.

But first let us establish that there is something puzzling about Michael's shopping bag. To begin with, it is repeatedly mentioned: seven times in all, often preceded by the adjective empty. The commonest phrasing is Michael...with the empty shopping bag, so that it becomes in the story his most distinguishing feature. Why is Michael carrying a shopping bag at all? In 
our discussions of this point, it was suggested that the empty shopping bag was vaguely symbolic of the scrotum, and of Michael's impotence. This might seem fanciful but for the fact that at the very point in the story when Michael is 'rescued' by Agnes and Denis, his "impotent rage" is mentioned, and this is interrupted by the capable Denis blowing his "horn":

It was in this impotent rage that he heard the horn blow. Denis was there and Agnes was in the car. He went towards them with the empty shopping bag. (p. 87)

We also believe there is a powerful verisimilar motivation for Michael's carrying of the shopping bag, on the couple's daily visits to Tesco's. But to make the purpose clear, it is worth clarifying what the text might allow us to assume. The reader seems allowed to assume that on an ordinary day Agnes would leave Tesco's with all her shopping bagged up in those thin plastic carrier bags that, at least at the time when the story is set, UK supermarkets gave out free. Agnes would then collect Michael, walk him to the pub, leave him there, take the shopping home, put it away, and have his lunch ready by the time he got back from the pub. So what purpose is there for Michael's empty shopping bag?

We suggest that this circumstantial detail is a brilliant (brilliant also because left narratorially unexplained) observed detail about certain notions of propriety and respectability within a certain social class of the time McGahern was writing about. That social group depicted are perhaps working class and of Irish origin, but the behaviour probably extends wider than this. People of that class and at that time - especially someone as hypersensitive about 'what people will think (of me/us)' as Michael - did not carry their shopping home in the 'vulgar' plastic bags provided by the supermarket, which were typically semi-transparent so that the neighbours could see just what sort of cornflakes and bacon you had bought. We speculate that (McGahern conceived that) the couple's routine would be for Agnes to bring the Tesco bags of shopping out of the supermarket, their contents then to be transferred to Michael's discreet all-concealing bag, this to be carried by him as far as the pub.

\section{Narrative embedding by analeptic projection}

One thing we can say, of this story and of quite a few McGahern stories, is that orthodox narrative prospection (the reader's mindfulness, in the course of reading, of what seems likely to happen next, and finally) is not a foremost consideration. "Impossible Things" is quite retrospective, with low narrative dynamism. Here, some kinds of suspense are banished, and some kinds of closure are announced, in the very first sentence:

They were out coursing on Sunday a last time together but they did not know it, the two friends, James Sharkey and Tom Lennon, a teacher and an agricultural instructor. (p. 90, bold added)

So the reader may infer that an elegiac farewell, the negotiation of a transition or passing, is more centrally the theme. Not that things are going to change (that is 'pre-announced'), but how one or more people (such as Sharkey) are going to cope with the change: that is the story theme. As much in fact could be said about "Creatures": Mrs Waldron's husband has died, so that transition has happened (and in its wake, smaller changes such as the likely departure into coupledom of her daughter Eileen, like her other children, is reported as imminent). What is to be narrated is how Mrs Waldron will negotiate this fading of the light (as the story puts things). 
There is a simple grammatical clue in this McGahern story that suggests it will be elegiac and retrospective as much as it will be driven forward, i.e. a clue that it will be low in narrativity: the frequency of past perfect reporting, effecting analepses to earlier times and events than the narrative present. Here is a typical instance from "Creatures", about Mrs Waldron's beloved cat, Fats:

She had started to hunt again and had brought mice and small birds, even a frog, into the bedroom through the partially open window as she had done in Castlebar when she was young. (p. 326)

As is well recognised, there is no requirement that for consistency the past perfect must be continually marked in a narrative analepsis (where simple past is used for the story present): more often there is a return to use of the simple past, but on the understanding that the entire narrated passage introduced by a distant past marker (i.e. auxiliary had) refers to that distant past occasion. Even so, the item had - which admittedly will sometimes be a main verb, not an auxiliary - occurs 71 times in "Creatures", comprising $1.2 \%$ of the text, twice as frequent here as it is in the British National Corpus sample of imaginative writing and the British Books section of the Cobuild Bank of English (both frequencies are close to $0.6 \%$ ). This is some quantitative indication of a strongly analeptic or retrospective tendency (low narrative dynamism) in this story. The frequency of had is elevated also, but to a lesser degree, in "A Slip Up" (at 0.91\%); while that in "Impossible Things" is close to the reference norm, at $0.54 \%$.

\section{Corpus stylistic analysis of "Creatures of the Earth"}

For several of the following sections, we will particularly use the text-processing software suites called WordSmith Tools and Wmatrix, both of which are becoming widelyused by stylisticians to make both preliminary and more probing lexical and semantic searches of literary texts. WordSmith Tools [Scott 2004] enable the text-analyst to generate word-frequency lists; calculate a text's keywords; generate its word clusters (also known as ngrams or lexical bundles); and produce a concordance for any word in the target text. Wmatrix [Rayson 2003, 2008] does some of the same tasks, and also offers an automatic semantic analysis of present-day (and historical) English texts (spoken and written), calculates key semantic domains, and provides a part-of-speech tag of every lexical item or multi-word expression (with 97\% accuracy). The semantic tagging assigns a semantic tag to every word of the text (with a claimed 92\% accuracy), there being 21 discourse fields and approximately 200 semantic categories.

\section{1. "Creatures of the Earth": a synopsis}

One of the advantages of taking a corpus-based approach to stylistic analysis is that the results of a corpus analysis can be used to test an initial intuitive response to a text. For this reason it will be useful to provide a brief summary of "Creatures of the Earth" and some of our initial reactions to it.

"Creatures of the Earth" is a strange story that focuses on a character called Mrs Waldron. After her husband's death, she and her daughter Eileen move to their summer cottage, having sold Mr Waldron's cattle and horses. The only thing they take with them is their much-loved cat, Fats. Mrs Waldron begins taking walks by the harbour, where she meets Tommy McHugh, a man with five grown-up children who spends his time watching sheep. 
Tommy has a collie dog that Mrs Waldron is very fond of, but her attitude towards Tommy himself begins to change when he starts mistreating the dog. One day, while Mrs Waldron is talking to Tommy, two young men, Murphy and Heslin, on an impulse take her cat, torture it and leave it to die. Mrs Waldron is overcome with grief, and cannot help but speak abruptly to Tommy. Tommy then tells his collie that Mrs Waldron is "on her way out", apparently secure in the knowledge that "they alone among all the creatures of the earth would never have to go that way." An initial intuitive reaction to the story is that a sense of sadness pervades the text world. There is a wistful tone to the storytelling and an overriding sense that unhappiness is a key part of each character's life. The analysis that follows is intended to uncover some of the textual sources of these initial responses.

\subsection{Key semantic domains}

What is important in "Creatures"? Wmatrix can be used to identify the story's main semantic domains, i.e. the semantic domains to which more of the story's words belong, by comparison with a 'normal' frequency, in a comparable text, of words from all the various semantic domains of English vocabulary. Identifying a text's prominent or disproportionately frequent semantic domains in this way is inevitably a matter of making comparison. In all the calculations below, the sample of texts used to enable such comparing, usually known as the 'reference corpus', was the 226,000-word sample of 'imaginative literature' taken from the British National Corpus, this sample being one of the standard options already loaded into the Wmatrix software. Our interest in the disproportionately-present semantic domains of "Creatures" lies in the possibility that an identification of the key semantic domains might help us to identify important themes or issues in the story. In Table 8 below, the top fourteen semantic domains, in order of textual prominence, are listed (column 3), preceded by a simple ranking (column 1). The log-likelihood score of the domain's keyness can be found in column 2. A log-likelihood score of 15.13 and over indicates $99.99 \%$ confidence of statistical significance $(\mathrm{p}<0.0001$ d.f.). Example words from the story can be found in the fourth column. In effect the Table tells us, for example, that the software judges that the semantic domain GEOGRAPHICAL TERMS is exceptionally prominent in the story, and does so on the grounds that words such as tide, island, sea etc. are relatively frequent in the text.

\begin{tabular}{|l|l|l|l|}
\hline No. & LL & Domain & Examples \\
\hline 1 & 96.01 & $\begin{array}{l}\text { Living creatures: animals, birds, } \\
\text { etc. }\end{array}$ & cat, sheep, fish, shark, trout, collie \\
\hline 2 & 73.64 & Geographical terms & tide, island, sea, stream, bay, earth \\
\hline 3 & 54.64 & Grammatical bin & the, and,, , , of, in, had, on \\
\hline 4 & 53.47 & Alive & life, lives \\
\hline 5 & 51.24 & Light & light \\
\hline 6 & 51.24 & Degree & as \\
\hline 7 & 43.64 & Sailing, swimming, etc. & boats, harbour, oars, boat, pier \\
\hline 8 & 30.67 & Time: General & ever \\
\hline 9 & 24.63 & Substances and materials: Liquid & water, froth, tar, wet, oil, drop \\
\hline 10 & 19.22 & Architecture, houses and buildings & cottage, house, hut, shelter \\
\hline 11 & 18.82 & Quantities: little & single, empty \\
\hline 12 & 18.29 & Substances and materials: Solid & canvas, sand, fur, leather, plastic \\
\hline 13 & 15.27 & Long, tall and wide & high, long, wide, deep, thick \\
\hline
\end{tabular}

Table 8: Key Semantic Domains in "Creatures" 
Before going further, and in the interests of cross-story comparison, we show how the above tendencies compare with the semantic prominences in "Impossible Things" and "A Slip-up", again using the BNC Sampler of Written Imaginative Prose as reference corpus.

\begin{tabular}{|l|l|l|l|}
\hline No. & LL & Domain & Examples \\
\hline 1 & 116.14 & Education in general & teacher, instructor, school, exam \\
\hline 2 & 66.28 & Unmatched & you, that, , no, if, what, it \\
\hline 3 & 30.80 & Degree & as \\
\hline 4 & 25.85 & Clothes and personal belongings & hat, wear, wore, towel, cap \\
\hline 5 & 23.10 & Light & glimmer, lighter, light \\
\hline 6 & 19.43 & Weak & frail, vulnerable, weak, weakly \\
\hline 7 & 17.62 & Grammatical bin & the, and, to, a, of, in, as, for \\
\hline 8 & 17.55 & $\begin{array}{l}\text { Living creatures: animals, birds } \\
\text { etc. }\end{array}$ & $\begin{array}{l}\text { hare, hounds, hares, fawn, mongrel, } \\
\text { horse, paws }\end{array}$ \\
\hline 9 & 16.13 & Competitive & raced, racing \\
\hline 10 & 15.40 & Darkness & dark \\
\hline 11 & 15.37 & Time: beginning & permanent, eternal \\
\hline 12 & 14.21 & Drinks and alcohol & whiskey, bar \\
\hline 13 & 13.59 & Substances and materials: liquid & water, oil \\
\hline
\end{tabular}

Table 9: Key Semantic Domains in "Impossible Things"

\begin{tabular}{|l|l|l|l|}
\hline No. & LL & Domain & Examples \\
\hline 1 & 58.92 & Plants & garden, hedges, stalks, thorns \\
\hline 2 & 56.79 & Farming \& Horticulture & farm, fields, field, \\
\hline 3 & 36.59 & Light & lights, light \\
\hline 4 & 34.89 & Quantities: little & empty, single \\
\hline 5 & 26.25 & Unemployed & retired, retiring \\
\hline 6 & 23.98 & Drinks and alcohol & $\begin{array}{l}\text { drank, off-licence, saloon, brandy, } \\
\text { drink }\end{array}$ \\
\hline 7 & 21.29 & Geographical terms & lakes, lake, pool, earth, stream \\
\hline 8 & 19.44 & Grammatical bin & the, and, to, of, in, a, with, when \\
\hline 9 & 18.39 & Objects generally & bottle, barbed wire, strands \\
\hline 10 & 18.30 & Darkness & dark \\
\hline 11 & 14.12 & Religion and the supernatural & christmas \\
\hline 12 & 13.02 & Evaluation: inaccurate & missed, slip-up \\
\hline 13 & 11.76 & Time: period & days, minutes, day, years, waited \\
\hline
\end{tabular}

Table 10: Key Semantic Domains in "A Slip-up"

Returning now to "Creatures", we will first examine some of the stylistically interesting key semantic domains, before looking at the top key semantic domain of LIVING CREATURES. 
A key domain analysis can thus start to account for what we view as the important themes in a story. Furthermore, such an analysis can also provide a lexical underpinning of the feelings and emotions we might have as we read a story. For example, Creatures of the Earth conveys a profound sense of wistfulness and sadness. Misery is another emotion that seems common in the text world, and examining the content of the key semantic domains of the story can give an insight into where these emotions are based, textually.

For instance, the following concordance lines (in 'Key Word in Context' format (often abbreviated to KWIC: the node word of particular interest is highlighted in the middle of the line, flanked by its co-text) make up the TIME: GENERAL domain:

the power and beauty of the ocean, ever changing. What did he see there? A never tired or dispirited. Love is ever watchful and lively and at ease. Th

$t$, Mrs Waldron was more eager than ever to get back to Achill. For the time ng collie who cowered now more than ever when approached. This changed her $\mathrm{m}$

$r$, and she was beginning to regret ever having come to know him . While Mrs

. "Was her mind at ease ? Love was ever watchful . But was there a final goi

Here, the node word ever appears to evoke a sense of wistful reflection. Ever occurs in reference to nothing staying the same. Related to this, a sense of sadness is perhaps evoked by the content of the QUANTITIES: LITTLE domain:

She went by the harbour. It was empty now of boats except for four old cu
from the summit and was completely empty. The tide was about to turn, and
ling back underneath the froth. A single man followed them out and searched
he flesh was the shark's tail : a single flick would make match-wood of the
uld come in during the course of a single evening. Murphy and Heslin watched

There is little sense of positivity in this domain and this seems to tie in with the story's unhappy mood of emptiness and solitariness. What is also interesting are the presuppositions inherent in the words that constitute this semantic domain. Using the word single, for example, is not necessary (cf. a man, a flick and an evening) but by incorporating this modifying adjective into the noun phrase McGahern draws attention to solitariness. By the same token, the use of 'empty' goes so far as to specify a lack.

This negative sense is also to be found in the SUBSTANCES AND MATERIALS: LIQUID domain. This domain exhibits what Louw [1993] would term a negative semantic prosody. Semantic prosody refers to the habitual semantic associations that a word may have, and Louw [1993] attributes the term to John Sinclair. Hunston [2007] criticises the concept on the grounds that the attitudinal meaning of a word may depend on the point of view of the analyst, and suggests that semantic prosody as a term is restricted to "the discourse function of a unit of meaning" [Hunston 2007: 266]. In reference to attitudinal meaning, she suggests that semantic preference may be a more appropriate term. Whatever terminology we choose, it is clear that the liquids in the story are firmly associated with negativity, as indicated by the concordance lines below:

In wild, wet January weather, two months after

is shoulder whenever the grass was wet . All through his final illness the looked gravely down on the surging water of the Sound. The cottage was by a 've not been drinking ? " " Not a drop . But I intend to have a stiff drin the harbour they were scraping and tarring the boats. A man was lovingly meas ering it with a boiling mixture of tar and pitch from a tin jug. She love 
She loved the smell of the boiling tar in the sea air. There was a crazy ieved in the healing properties of tar, and each summer he tarred his ten erties of tar, and each summer he tarred his ten children from head to toe . $\mathrm{n}$, and they walked far out to the water 's edge, a white froth marking the out to the water 's edge, a white froth marking the tideline, a gentle, $d$ ine, a gentle, dirty backwash of water and sand curling back underneath th $\mathrm{d}$ sand curling back underneath the froth . A single man followed them out an ed them out and searched along the froth until he found a green plastic oil oth until he found a green plastic oil can which marked a set line. He th hut and carried upside down to the water. There were four men to each curra with eight legs advancing into the water. There they floated the boats and e as they bobbed listlessly on the water, the men resting on their oars wit e air as it was flung out over the water. She had to get away quickly . " W

We can note, for example, that January weather is wet when Mrs Waldron shuts up the house and leaves it after her husband has died; the black cat looks "gravely down on the surging water of the Sound" (this is especially significant when we consider that the cat ends up getting drowned); the tar is a "boiling mixture" and the following reference is to a man tarring "his ten children".

In stark contrast to the SUBSTANCES AND MATERIALS: LIQUID domain is SUBSTANCES AND MATERIALS: SOLID. The node words that make up this domain are highlighted in the concordance lines below:

he bed, burying her face in the fur , and left the darkened room to $t$ he traditional way, with a blue stone slate roof and a small porch in $\mathrm{f}$ ditional way, with a blue stone slate roof and a small porch in front . st the storms. There were a few wooden crayfish creels along the short $p$ $\mathrm{s}$ lovingly measuring a square of calico over weakened timbers before cove efore covering it with a boiling mixture of tar and pitch from a tin jug . mixture of tar and pitch from a tin jug. She loved the smell of the a thick jersey of unwashed grey wool with a worn black suit and a clot and turned on the big square of gravel. Instead of coming straight into rring as the cat curled into the eiderdown, declaring to all her own approv ving hay. There was much broken glass along the roads. Eileen had take their throats so that the light cotton floated out behind them in the oc ransistor. Heslin had a large, canvas bag slung from his shoulder in wh went towards them and rubbed her fur against the bars of the gate. As ng hands and thrust her into the canvas bag. The cat alternately tore an ssively in red helmets and black leather, a blue insignia painted on the en the cars and the strand. The sand was as white and unspoiled as it le, dirty backwash of water and sand curling back underneath the froth the froth until he found a green plastic oil can which marked a set line . , freshly baiting each one with sand eels taken from a red plastic buc with sand eels taken from a red plastic bucket. His catch was small, th attracted by the cries from the canvas bag, but he did n't appear to no 't appear to notice. Throwing a metal weight on the end of the line far

Rayson [2008] notes that Wmatrix is particularly useful for generating candidate research questions, and in the above two concordances we see a clear indication of this. It is interesting to note that materiality is such a strong element of this story and we might well ask what the 
function of liquids and solids is in this story. A full answer to this question is beyond the scope of the present paper, though we might note that liquids and solids are conventional opposites. In a study of opposition in literary contexts, Jeffries [2010] suggests that conventional oppositions are common in novels and that such devices are often used to "set up the oppositions which will be relevant to the narrative to follow" [2009: 77]. From this we might note the role that liquids play in generating much of the negativity in the story, and how this is often connected to the items that appear in the SOLIDS concordance. The cat, for example, is thrust into a canvas bag and drowned in water.

Of all the semantic fields in the story, however, it is LIVING CREATURES that emerges by a clear margin as the most key semantic domain. Below we list a sample of twenty unconnected lines from the story, in which an item from this top semantic domain occurs:

reluctance it was agreed that the horses and the few cattle that had been $t$ greed that the horses and the few cattle that had been their father 's main not like the idea at first of his horses being sold, but had to admit that took was an old, trusting black cat they were all very attached to. $\mathrm{T}$ all very attached to. The black cat had four white paws and a white st to . The black cat had four white paws and a white star on her forehead a called Fats. In the evenings the cat used to wait for the surgeon 's ca nt over the fields to look at the cattle or horses the cat went with him , e fields to look at the cattle or horses the cat went with him, racing ahe look at the cattle or horses the cat went with him, racing ahead and c All through his final illness the cat slept at the foot of his bed. Whe in the eyes of most of these poor creatures. Now that I am sick I simply am $n$ $\mathrm{n}$ the days ahead. She lifted the cat from the foot of the bed, burying $\mathrm{s}$ Waldron said as she stroked the cat stretched like a lion on the dashb stroked the cat stretched like a lion on the dashboard of the car. The dashboard of the car. The black cat suddenly yawned, rose to her feet aldron tidied the house, fed the cat in the shelter of the porch, watc storms . There were a few wooden crayfish creels along the short pier wall a she could choose between several sheep paths through the heather, but ge their kitchen gardens, spreading manure and seaweed, shovelling the rich

the colours you watch or the sea birds or just the ocean itself? " " I' ike that . I'd be watching those sheep over there. " He gestured towards rehand grew into clear shapes . "Sheep are very stupid animals, " he con

There is clearly an underpinning, in the lexical evidence, to this semantic categorization. What we notice here is that, with one exception, ('most of these poor creatures'), the words that make up this key domain refer to animals (as opposed, say, to the use of creatures to refer to humans). As we will argue below, this overwhelming focus on animals is likely to lead the reader to interpret the word creatures as characterising humans as animalistic.

\subsection{Keywords}

In addition to analysing key semantic domains, we can use WordSmith Tools' Keyword function to identify the story's top keywords, i.e. the words which are disproportionately frequent in the story by comparison with a suitable reference corpus such as the BNC Imaginative Literature sample. Again, for ease of subsequent reference, we list below not only the top keywords in "Creatures", but also those in "Slip-up" and in "Impossible Things". 
Top keywords in "Creatures" (using BNC imag lit sample): cat, Eileen, Heslin, Murphy, Castlebar, Mrs Waldron, the ocean, Waldron, island, sea, the, they, Tommy McHugh, strand, cottage, tide, boats, stools, she, stream, collie, sand, harbour

Top keywords in "Creatures" (using a half-million word corpus of modern fiction as reference corpus): cat, Waldron, Heslin, Eileen, Murphy, Castlebar, cottage, boats, ocean, tide, McHugh, they, collie, stools, the, Tommy

Top keywords in "Slip-up": Agnes, Denis, he'd, n't, Tesco's, Michael, Bass, he, shopping bag, we'e I'll, farm, bottle, lake, lakes, retired, when, royal

Top keywords in "Impossible Things": teacher, Charlie, Tom Lennon, the, hat, whiskey, that, instructor, he, hounds, Sunday, hare, fawn, exam

In all these data-manipulations there is a danger of drowning in the detail, so we want first to emphasize that in "Creatures" the first positive key word that is not a proper noun is a noun that belongs to a semantic field (LIVING CREATURES) already identified as key, and that word is cat. For that reason alone, we would argue that the multiple uses of cat (the phrases in which it collocates, any tendencies in its semantic import, any co-referential chain in which it participates) especially merit further examination. Incidentally we note that using a different reference corpus than the BNC imaginative lit sample will yield a slightly different group and ordering of the story's keywords, but both calculations confirm cat as far and away the top keyword.

If we now look at how the word cat is used in the story, a number of interesting issues arise. The cat is only referred to by its name four times: once by the narrator when it is introduced into the story ("The black cat had four white paws and a white star on her forehead and was called Fats"), and three times in the direct speech of Mrs Waldron and Eileen ("Did anything happen to Fats while I was away?' Eileen asked", "Mrs Waldron said, 'Fats won't come back now", and "Fats marked thirteen years of intense happiness"). All other narratorial references to the animal use the definite noun phrase the * cat (the asterisk is a 'wildcard' which tells WordSmith to extract all instances of the noun phrase the cat, including those which incorporate pre-modifying adjectives before the head noun). This might be said to reflect the external point of view of the narrator, which contrasts with the psychological closeness that Mrs Waldron and Eileen feel towards the cat. It is also perhaps ironic that that cat tends not to be referred to by name, considering its pivotal role in the story. These intuitions can be verified by examining concordances of the *cat, to see how the phrase is used in the story. Below are all such instances of the phrase, along with indicators (underlined) of what Louw [1993] would term its semantic prosody:

They counted back the years that the cat had been part of their lives. She had been

" Eileen asked suddenly, missing the cat for the first time and anxious to change the e excitement of Eileen's return, the cat was forgotten. The presents she brought - a rphy replied. Mrs Waldron missed the cat as soon as she came through the gate, so video of what happened to the fukken cat?" Murphy replied. Mrs Waldron missed the cat ut they weren't able to pick out the cat being tossed about on any of the low waves. leaving the beach. By then the black cat, through drowning or struggling or pure and seemed to notice the struggling cat. As he approached, Murphy and Heslin turned

ttles of beer. Behind them the black cat struggled against the incoming tide. An ore she could claw herself free. The cat shot away but was held by the line and rock. 
into the bag Murphy still held. The cat cried, then went still, and he searched about e ocean. They descended quickly, the cat crying and struggling in the bag. An ugly, passed the bar. "Not with the bloody cat." "What'll you do with it?" "I'm not sure.

thrust her into the canvas bag. The cat alternately tore and struggled, or cried never rose before midday. The black cat was waiting between the gate and escallonias nything, and after feeding the black cat she cleaned the entire cottage. Then she went us licking, then loud purring as the cat curled into the eiderdown, declaring to all $\mathrm{d}$ to do on his return from work. The cat, at least, seemed to have taken on a new $\mathrm{ul}$ and lively and at ease. The black cat was waiting for her return to the cottage. rs Waldron tidied the house, fed the cat in the shelter of the porch, watching her the dashboard of the car. The black cat suddenly yawned, rose to her feet and looked Mrs Waldron said as she stroked the cat stretched like a lion on the dashboard of the ce in the days ahead. She lifted the cat from the foot of the bed, burying her face in

t. All through his final illness the cat slept at the foot of his bed. Whenever Mrs to look at the cattle or horses the cat went with him, racing ahead and crying to be was called Fats. In the evenings the cat used to wait for the surgeon's car to come were all very attached to. The black cat had four white paws and a white star on her

What is apparent from the above concordance is that the phrase the * cat has a strong attitudinal association with cruelty (as a result of the torture it suffers) and sadness (as a result of the feelings of absence it inspires, its association with Mr Waldron's illness and its waiting for Mrs Waldron). The semantic prosody of cruelty is seen particularly when we consider what the cat does in the story; i.e. what dynamic verbs it is associated with:

the black cat struggled against the incoming tide

The cat shot away

The cat cried

The cat alternately tore and struggled, or cried plaintively

The black cat was waiting between the gate

The cat curled into the eiderdown

The black cat was waiting for her return to the cottage

The black cat suddenly yawned, rose to her feet and looked gravely down

All through his final illness the cat slept at the foot of his bed

the cat went with him, racing ahead and crying to be lifted on to his shoulder

the cat used to wait for the surgeon's car

What we can notice here is that the cat is doing things in response to other events, rather than of its own volition. It is reacting to unpleasant and cruel things that are done to it and even those actions that seem more positive (curling and sleeping, for example) are carried out in the context of unpleasant or sad events (Mr Waldron dying, for example).

What, then, is the significance of all this for the story as a whole and how might we interpret these findings with regard to McGahern's artistry? What is apparent in this fairly brief analysis is that the cat plays a central role in the story and is a focal point for the unpleasant events that happen. It is also the case that the cat reacts and responds to unpleasant events rather than being the cause of them. In this respect we might see a discoursal parallelism with the character of Mrs Waldron. She too reacts and responds to unpleasant events rather than being a direct cause of them. Unpleasant things happen to her as opposed to her being the instigator of unpleasant events. This discoursal parallelism is reinforced by the fact that we are arguably pushed to understand the title word creatures to characterise humans as animals, since all other references within this key semantic domain are to non-human 
animals. In such a conceptualisation there is no distinction between the two. This takes us back to the first key semantic domain of the story: LIVING CREATURES. Given that creatures is the head word of the title noun phrase it would seem appropriate to look at its usage in the story. What we find is that creatures appears just twice: once at the beginning of the story and once at the end. In the first instance of its use, $\mathrm{Mr}$ and Mrs Waldron are discussing why Mr Waldron's colleagues have been avoiding him since he became ill. $\mathrm{Mr}$ Waldron, a doctor, speaks first:

"We are no longer useful. It is as simple as that."

"It can't be that simple."

"Not complicated, then, either. They work with sick people but they are not ill. They are outside and above all that. They have to be. They loom like gods in the eyes of most of these poor creatures. Now that I am sick I simply am no longer part of the necessary lie that works. I have to be shut out. Gods can never appear ill or wounded." (p. 321)

Here, creatures is used to refer to sick people and appears to contrast with gods, the opposition being triggered by the presupposition inherent in the line "Gods can never appear ill or wounded." The second and final use of the word creatures occurs in the last paragraph of the novel, where Tommy McHugh is talking to his collie and delivering his opinion concerning Mrs Waldron:

"[...] Let me tell it to you for now and for ever and for world without end, Amen, deliver us, lad, that yon old bird is on her sweet effing way out," he declared to the absent collie in a voice that sang out that they alone among all the creatures of the earth would never have to go that way. (p. 335)

The fact that the word creatures appears, after the title, only at the beginning and end of the story foregrounds it. The word is further foregrounded by the fact that, of the words in the story from the semantic domain of LIVING CREATURES, it is the only one that refers to humans. Furthermore, we might note that there is a clear negative semantic prosody associated with the other lexical items in this category that imbues creatures with the same negative associations (note, for example, the references to "the few cattle, horses being sold, All through his final illness the cat slept, few wooden crayfish creels, Sheep are very stupid animals", etc.). McGahern's skill appears to have been to control these connections, even if unconsciously, thereby creating a parallel between the humans in the story and the dumb creatures of the earth. Etymologically and semantically, to be a creature is also to be mortal, and part of what is absurdly uncharitable about Tommy McHugh is that he alone fantasizes that he is not similarly mortal. There may be a link here with the topics of face/humiliation and judgementalism discussed earlier; and, especially in the uses of $f e w$ here, also with the negation topic which we began with. There is implicit semantic negation ('not many') in the phrases using words from the LIVING CREATURE domain such as the few cattle and a few wooden crayfish creels: compare several cattle, several crayfish creels.

\section{Reader-immersion in the story situation}

In this final section we draw in part on features of McGahern's style noted earlier, but now in relation to how the texture of his writing enables the experience that some readers report, of feeling powerfully 'immersed' in his story situations (and feeling, inter alia, the 
"strange ache in the heart" that we reported from O'Connor in our opening paragraph). We believe that a precondition for emotional reader-immersion is that the narrative text creates a credible scene, a believable position in the story world. This in turn is achieved and relayed to the reader, in part, by the language of volitive modality and evaluative mental reaction: disclosures to the reader of what a sympathetic character wishes, wants, laments, desires, fears, is enraged by, and so on. These are among the standard linguistic means of disclosing the preoccupations of a projected consciousness. Immersion or engagement is a matter of drawing the reader into empathy or sympathy with a depicted character, achieved by furnishing the textual means with which the reader can 'see into' or see along with that character's imagined consciousness, and this is why consciousness-projection via desire modality (will, would, wanted to, hated to, gladly) and mental process verbs of evaluative reaction (like, hate, fear, admire, resent, etc.) are important default or canonical contributors to the establishing of reader involvement. Different stories of course use different forms, and as soon as standard or congruent resources emerge, there is some pressure for writers to devise more indirect or oblique means of expressing emotional heightening.

In "Creatures", we propose that the most emotionally moving (distressing, chilling) moments are those during which we witness the sadistic drowning of Fats by the two young men and - perhaps even more shocking - the abrupt disclosure by Tommy McHugh that he has tired of his dog's lack of discipline and thrown him over the cliff to his death. When Tommy tells Mrs Waldron this the narrative reports:

She heard and didn't hear. She could see the petrified black-and-white shape blur in the air as it was flung out over the water. She had to get away quickly.

"Well. I'm glad to see you too," she said as she started to move away. (p. 334335)

Here, the positive and negative polarity (as discussed in section 2) applied to the character's reported mental processing of Tommy's words (she heard and didn't hear) is powerfully emotionally engaging of the reader. Here too is a modalized mental process, in the affirmative (she could see) where we understand that she did not literally see, but that this is so shocking an imagined scene to her that it is made real or visible. And what Tommy's words do to Mrs Waldron, we hypothesize, this passage's words do, in the way of emotional arrest, to the reader. This brief episode ends with conflicting volitive modalities, quite as contradictory as the hearing and not hearing in the first sentence: Mrs Waldron says she is glad to see Tommy, but the narration more truthfully reports she had to get away quickly.

In "A Slip-up" the emotional high-point, we suggest, comes in the paragraphs towards the close where Michael, ashamed of his lapse, suspects that the pub regulars' unusually warm welcome (discussed in section 2 above) is only masking their pleasure at his humiliation. That suspicion of their hostile pleasure is articulated in a passage that is too formal to be Free Indirect Thought but clearly narrates the grotesquely disproportionate comparison that has come to Michael's mind:

All the people were elated too on the small farms around the lakes for weeks after Fraser Woods had tried to hang himself from a branch of an apple tree in his garden, the unconcealed excitement in their voices as they said, "Isn't it terrible what happened to poor Fraser?" and the lust on their faces as they waited for their excitement to be mirrored. (p. 89)

What is the key stylistic marker of emotion here? Using Wmatrix to classify the semantic domains invoked in this sentence, one of the most prominent is reflected in the two 
occurrences of excitement, classified as instances as category X5.2+, which covers the meanings 'interested/ excited/ energetic'. Arguably two more words in the sentence fall into the same semantic domain, even though Wmatrix assigns them to other tagsets: elated and lust. The excitement, elation, or lust of the farming people at the news that Fraser Woods tried to hang himself is the dominant reported emotion. It hardly needs saying that these are distasteful and perverted emotions, and imply a twisted mentality in Michael himself. We would suspect that readers do not empathize with Michael at this point, but rather find these lines disturbing; so the represented emotions, arguably, prompt strong but contrasting feelings (e.g. of revulsion) in the reader. But what guides the reader towards a secret sharing of Michael's emotions before a reconsideration of their content prompts our rejection of them are the verbal markers of mental reaction that fall somewhere between desire and evaluation. And importantly, these mental processes are linked to at least implicit projected propositions: the people are not excited and elated intransitively, but excited/elated/lusting that Fraser Woods has tried to kill himself.

The mention of Wmatrix's semantic tagging of the 'high-emotion-associated' lexis in a text prompts further questions as to whether automated text-mining and -analyses may be useful more generally here. Turning to our third McGahern story, "Impossible Things", can a semantic text-parser help to highlight the lexis most instrumental in emotion-generation?

Among the categories in Wmatrix's comprehensive array of semantic tags, the supercategory X2 covers all 'Mental actions and processes'; since this embraces words to do with learning, understanding, and expecting (or not), this on its own may be rather too indiscriminate for the analyst most interested in emotion-implicating mental reactions. One of the sub-categories is X2.1 (covering 'thought, belief'), which captures nouns or verbs such as think, believe, regard, imagine, feel, suppose, impression, conviction, judgement, consider, guess, find. In "Impossible Things", much the most prominent item falling into the X2.1 category is felt (it is 10 of the text's instances that are automatically allocated to this category, with thinking, occurring 5 times, as next most frequent). A further reason for focussing on instances of felt is its relative prominence among all the text's past tense action verbs. Wmatrix can automatically extract and count these. There are 239 in the text; unsurprisingly, said is most frequent (27 instances), but interestingly felt is next most frequent, occurring 10 times and featuring more often than such standard narrative verbs as went, took, asked, began, wore, watched, stood, and saw.

A close look at how felt is used in "Impossible Things" reveals that it is prominent in all three passages that one might propose as the story's most emotional scenes: where James Sharkey tests to destruction Cathleen O'Neill's commitment to him; where he acts as barber to his friend Tom Lennon; and finally when he takes possession of Tom's greyhound and his mind races with "impossible things". Space limitations prevent a closer study of the narration using felt in the first of these scenes - where we encounter sentences like "As she passed through the gate he felt a tearing that broke as an inaudible cry" and "He felt his whole life like a stone on the edge of a boat out on water".

In the later two scenes, uses of felt occur in a single, long and involved sentence, crucial to the story's disclosure of James Sharkey's most private self. The two sentences are at the heart of scenes which constitute the mid-point and the end-point of the action and progression. The first of these is the long sentence describing Sharkey cutting his old friend's hair, in preparation for the latter's examination. Here and below, instances of felt are highlighted in bold:

He [Tom Lennon] wanted a haircut, and that night, as the teacher wrapped the towel round the instructor's neck and took the bright clippers out of their palegreen cardboard box, adjusting the combs, and started to clip, the black hair 
dribbling down on the towel, he felt for the first time ever a mad desire to remove his hat and stand bareheaded in the room, as if for the first time in years he felt himself in the presence of something sacred. (p. 101)

The second sentence is even longer and more striking, and is spontaneously recognized by many readers as the climax of the story. It is its penultimate sentence, reproduced here with the final one, so that the contrasting rhythm of the two, the jointly created cadence, can be noted:

As he petted her down, gripping her neck, bringing his own face down to hers, thinking how he had come by her, he felt the same rush of feeling as he had felt when he watched the locks of hair fall on to the towel round the neck in the room; but instead of prayer he now felt a wild longing to throw his hat away and walk round the world bareheaded, find some girl, not necessarily Cathleen O'Neill, but any young girl, and go to the sea with her as he used to, leave the car at the harbour wall and take the boat for the island, the engine beating like a good heart under the deck boards as the waves rocked it on turning out of the harbour, hold her in one long embrace all night between the hotel sheets; or train the fawn again, feed her the best steak from town, walk her four miles every day for months, stand in the mud and rain again and see her as Coolcarra Queen race through the field in the Rockingham Stakes, see the judge gallop over to the rope on the old fat horse, and this time lift high the red kerchief to give the Silver Cup to the Queen.

And until he calmed, and went into the house, his mind raced with desire for all sorts of such impossible things. (p. 103)

This penultimate sentence ( 212 words) is far and away the longest and most complex in the entire story, full of complex alternative or cumulative longings, cast as physical actions (throw his hat, walk around the world, find some girl, go to the sea, take the boat, hold her in one long embrace, train the fawn, stand in the mud, see her race, see the judge gallop and lift high the red kerchief...). Like several previous examples, the sentence construction takes the form 'As X [x: physical action or event], he felt $\mathrm{Y}$ [y: volitive desire to bring about other actions/events]', so that there is the enrichment of texture that simultaneity entails (cf. Labov's 'correlative evaluation').

Focussing on those narrative sentences in which felt is used also highlights several other things. One is simply that they seem to occur in comparatively long sentences, which is to say more involved sentences - if we are justified in claiming that a long sentence draws a reader in more than a short one, simply because, everything else being equal, this means that there are more interrelated propositions or images to be taken together by the reader. We know this intuitively from the long sentences of Faulkner or James. But in general McGahern does not write like those authors, which makes it all the more striking when he chooses to produce the kind of sentence like the one about Tom Lennon wanting a haircut, Sharkey obliging him, and then experiencing the "mad desire" to remove his hat and soon feeling as if "in the presence of something sacred". This sentence, not by accident we submit, also contains many of the kinds of volitive modality and mental highlighting discussed earlier: Lennon wanted a haircut... Sharkey felt... a mad desire to remove his hat... as if... he felt himself in the presence of something sacred.

Another link between the sentence just mentioned and the story's penultimate one, both reporting what Sharkey felt, is the way that the sense of liberating emotion is prompted by a particular kind of implicit intimacy: the touching of a neck. Sharkey touches Lennon's neck in the haircutting episode, and Coolcarra Queen's neck when he returns home from the funeral. 
Other parallels may be noted too: what was a "mad desire" in the earlier sentence is a "mad longing" in the later one; and what was sacred before is now more of this world: a night with a girl, or Coolcarra Queen trained and this time winning the Rockingham Stakes. The penultimate sentence is also important for creating the conditions in which the final sentence, when we read it, can be a perfect fit. In that final sentence it as if the excitement of the fawn, at the opening of the long sentence, has transferred completely to the man, caught up in exciting fantasies of the possible. There is a kind of lexical transfer: he has just imagined how Coolcarra Queen might race through the field, and now the same verb is used to describe his own over-active imagination: his mind raced with desire.

Unlike many grammatical descriptions, systemic linguistics includes temporal frequency or usuality as a kind of modality. This draws us to note the temporal staging of these last two sentences, as a subtle combination of the recurrent, the habitual, and the fantastically unique. Some of the most important temporal choreographing markers, outside the standard ones of tense and aspect attached to the verbs, are put in bold below:

As he petted her down, gripping her neck, bringing his own face down to hers, thinking how he had come by her, he felt the same rush of feeling as he had felt when he watched the locks of hair fall on to the towel round the neck in the room; but instead of prayer he now felt a wild longing to throw his hat away and walk round the world bareheaded, find some girl, not necessarily Cathleen O'Neill, but any young girl, and go to the sea with her as he used to, leave the car at the harbour wall and take the boat for the island, the engine beating like a good heart under the deck boards as the waves rocked it on turning out of the harbour, hold her in one long embrace all night between the hotel sheets; or train the fawn again, feed her the best steak from town, walk her four miles every day for months, stand in the mud and rain again and see her as Coolcarra Queen race through the field in the Rockingham Stakes, see the judge gallop over to the rope on the old fat horse, and this time lift high the red kerchief to give the Silver Cup to the Queen.

And until he calmed, and went into the house, his mind raced with desire for all sorts of such impossible things. (p. 103)

This highly emotive closing passage subtly presents in sequence a series of spatiotemporal scenes (or Bakhtinian chronotopes): a past incident, what Sharkey feels 'now', doing again what he has done before (what he used to do), then doing again what he has done before, and finally imagining a new outcome, one that has not happened before: this time. It is a remarkable shifting of times and tenses, really coming close to the limits of what would be deemed orthodoxly grammatically reportable within one sentence. This leads us to a point about scarcely grammatical sentences - and an explanation for them in emotionality.

McGahern, we suggest, has a stylistic preference for pushing the sentential envelope to the limits of grammatical orthodoxy - and sometimes beyond - particularly at or near the close of his stories, at their emotional peak. In this way he builds on what is achieved by resorting to a complex and lengthy sentence structure: the latter condition alone would make these final or near-final sentences especially engaging and attention-worthy. But when these atypically long sentences are also bordering on the ungrammatical they are doubly noticeable and arresting. Arguably all three stories we have analyzed in depth have a late, long, borderline-grammatical sentence: that in "Creatures", which contains Tommy McHugh's grotesque 'warning' to his absent dog, we discussed at the end of section 7. The counterpart in "A Slip-up" is the sentence filling the antepenultimate paragraph - All the people were elated... as they waited for their excitement to be mirrored.-already discussed above. The 
wretched and absurd comparison here, between people's suspected 'elation' at Michael's slipup and at Fraser's suicide is a narratorial adoption of Michael's disproportionate mindset, and the fractured grammar arguably fits the unsound reasoning. Similarly the long sentence in "Impossible Things" presses at the limits of orthodox grammaticality. Processing it is a challenge to the reader - less because of its chaining of multiple clauses than because of its ellipsis of such disambiguating material as that which we reintroduce in square brackets here:

or [he felt a wild longing to] train the fawn again... and to see the judge gallop over to the rope... and this time [to see the judge] lift high the red kerchief... (p. 103)

Again we would propose that such grammatical strain and turbulence is expressive of the emotional strain and turbulence in the focalized character, and is the more effective in not only conveying that strain to readers but causing them to feel it, in the linguistic form.

A final narratological point can be made about the last sentence of "All Sorts of Impossible Things" and the order in which it reports events. It is absolutely characteristic of McGahern's achronological style, always willing to tell early what happens finally (noted also in section 6 above), preferring to move us with the poignancy of the real than the lure of the seductively impossible. Here McGahern prefers to tell us first what finally happened (he calmed and went into the house), so that we know the wild longing cannot possibly be fulfilled, rather than having our hopes raised and then dashed, as the following 'unrearranged' order might have:

And his mind raced with desire for all sorts of such impossible things, until he calmed, and went into the house.

Perhaps the author has it both ways: the clause ordering puts the end-focus on "all sorts of such impossible things", and who can completely discount their possibility when they are the last thing mentioned (even if they are called "impossible")? The narrative implies that these things did not happen and will not happen, but the way it tells us this leaves our minds racing with the possibility that they could. McGahern has done the same thing, the same calculated misdirection, in the long sentence of imagining that comes just before. Sharkey does not take the boat out to the island with a young girl, but his imagining of it all, including the good heart of the boat's engine and the waves rocking them as they turn out of the harbour, is so particularly realized that the reader cannot help themselves picturing that which will not happen. These modalized impossibilities bring us back to the first feature of McGahern's distinct style noted in this article, his use of negation in narration.

\section{Conclusion}

As a headnote to this essay we used McGahern's simple powerful observation that everything interesting begins with one person in one place. That observation extends far beyond short story design, but we believe it fits McGahern's own stories where, typically, one person in one place - Michael, James Sharkey, Mrs Waldron - is closely observed, brought near to the reader, and becomes interesting. What we hope to have identified here are some of the central ways in which McGahern uses language to give voice and depth to these individuals. Those ways included: the powerful projection of alternative and often clashing perspectives by means of negative polarity expressions, in the direct speech and the narrative; an equally rapid achievement of depth (and reader immersion) via forms of embedded 
discourse, and small 'islands' of character direct speech; the psychological and narrative power of the humiliating instance, the barbed or suggestive phrase; exceptional reticence or restraint in the narration of certain kinds of story detail (such as Michael's 'unnarrated' empty shopping bag); and a preference for elegy and prolepsis, over plot and narrative dynamism. We also concluded, as confirmed by automatic semantic text-parsing, that the important late story "Creatures" (but possibly "Impossible Things" and other stories too) is shaped in part around a quite matter-of-fact and unromanticised assumption of a 'fraternity' of humans and animals, although this is often confronted by disturbing violations of that community (all brutes as the earth's 'children', but some men as brutes); and we argued that at the heart of all three stories the language of feeling was powerfully deployed to effect reader-immersion in characters' emotional turmoil, so that stories that begin as something interesting end as something moving. These ways, severally, are not unique to McGahern's style in kind or degree; but operating in combination they may be central to why his narrative art continues to be celebrated and identified as distinctly his own.

\section{Bibliography}

Biber D., Johansson S., Leech G., Conrad, S. \& Finegan E., Longman Grammar of Spoken and Written English, London, Longman/Pearson, 1999.

Clark Herbert H. \& Clark Eve V., Psychology and Language. An Introduction to Psycholinguistics, USA, Harcourt Brace Jovanovich, 1977.

GAVINS Joanna, "(Re)thinking modality: A text-world perspective", Journal of Literary Semantics 34:2, 2005: 79-94. (critiques and revises both Werth and Simpson)

GIvon Talmy, English Grammar. A Function-Based Introduction (Vol. I), Amsterdam \& Philadelphia, John Benjamins, 1993.

Halliday M. A. K. \& MATthiessen C., Introduction to Functional Grammar, $3^{\text {rd }}$ edition, London, Arnold, 2004.

HARMON Maurice, "Generations Apart: 1925-1975", in HARMON Maurice \& RAFROIDI Patrick (eds.), The Irish Novel in Our Time, Lille, Publications de l'Universite de Lille III, 1976: 49-65.

Hunston Susan, "Semantic prosody revisited", International Journal of Corpus Linguistics 12(2), 2007: 249-68.

ISRAEL Michael, "The Pragmatics of Polarity", in HORN Laurence R. \& WARD Gregory (eds.), The Handbook of Pragmatics, Oxford, Blackwell Publishing Ltd, 2004: 701-723.

JEFFRIES Lesley, Opposition in Discourse, London, Continuum, 2010.

JESPERSEN Otto, Negation in English and Other Languages, Copenhagen, Det Kgl. Danske Videnskabernes Selskab, 1917.

LAKOFF George, Don't Think of an Elephant! Know your Values and Frame the Debate: The Essential Guide for Progressives, Vermont, Chelsea Green Publishing, 2004.

LEECH Geoffrey, The Principles of Pragmatics, London, Longman, 1983.

LEECH Geoffrey and SHORT Mick, Style in Fiction, London, Longman (1981) 2007.

Louw Bill, "Irony in the text or insincerity in the writer? The diagnostic potential of semantic prosodies", in BAKER M., Francis G. \& TOGNINI-BOnElli E. (eds), Text and Technology: In Honour of John Sinclair, Amsterdam, John Benjamins, 1993: 157-176.

MaISOnNAT Claude (ed.), "The Short Stories of John McGahern", Special Issue of the Journal of the Short Story in English/Les Cahiers de la Nouvelle - n53, 2009.

MCGAHERN John, Creatures of the Earth: New and Selected Stories, London, Faber, 1992.

NøLKE Henning, "The Semantics of Polyphony (and the Pragmatics of Realization)", Acta Linguistica Hafniensia 38, 2006: 2-25. 
NøRgaARD Nina, "Disordered Collarettes and Uncovered Tables. Negative Polarity as a Stylistic Device in Joyce's 'Two Gallants"', Journal of Literary Semantics, 36, 2007: $35-52$.

O'ConNor Joseph, "Mine's a pint", Feature article on the work of John McGahern, The Guardian, Features \& reviews section, Saturday August 16, 2008: 17.

RAYSON Paul, Wmatrix Tutorial, 2008 : http://ucrel.lancs.ac.uk/wmatrix/tutoria

SEMINo Elena \& SHORT Mick, Corpus Stylistics, London, Routledge, 2004.

Werth Paul, Text Worlds: Representing conceptual space in discourse, London, Longman, 1999. 